\title{
TELAAH TEORITIS: APA ITU BELAJAR ?
}

\author{
Siti Ma'rifah Setiawati, S.Psi \\ Guru Bimbingan Dan Konseling MTs Negeri 4 Kota Surabaya \\ marifah0404@gmail.com
}

\begin{abstract}
Abstrak
Belajar adalah proses aktivitas yang dilakukan dengan sengaja untuk melakukan perubahan sikap dan perilaku yang keadaaannya berbeda dari sebelum individu berada dalam situasi belajar dan sesudah melakukan tindakan yang serupa dan yang bersifat menetap. Ada 4 ciri-ciri belajar yaitu : perubahan, bersifat permanen, adanya usaha, dan perubahan karena proses belajar. Aspek belajar atau tujuan belajar dibagi 3 bagian atau domain yaitu : Domain Kognitif, Domain Afektif, Domain Psikomotor. Ciri-ciri perubahan tingkah laku dalam pengertian belajar yaitu : Perubahan terjadi secara sadar, bersifat kontinu dan fungsional, bersifat Positif dan aktif, bukan bersifat sementara, bertujuan atau terarah, mencakup seluruh aspek tingkah laku. Faktorfaktor yang mempengaruhi hasil belajar yaitu faktor internal dan faktor eksternal. Hasil belajar siswa pada hakikatnya adalah perubahan tingkah laku sebagai hasil belajar, dalam arti luas mencakup bidang kognitif, afektif dan psikomotorik.
\end{abstract}

Kata kunci: Belajar, Perubahan perilaku.

\section{PENDAHULUAN}

Kebanyakan orang tua menyuruh anaknya untuk belajar tapi apakah mereka tahu apa itu belajar. Mereka beranggapan belajar itu aktifitas membaca, menghafal, dan mengerjakan PR. Bahkan setiap anak yang berangkat sekolah kalau ditanya mau apa? pasti dijawab mau belajar, tapi apakah mereka tahu apa belajar itu? Apakah kegiatan membaca, mendengarkan,menulis, mengerjakan tugas, dan ulangan itu dinamakan belajar? Seperti apa yang dinamakan belajar itu?. 


\section{DEFINISI BELAJAR}

Menurut beberapa ahli pengertian belajar itu sebagai berikut:

Menurut Ernest R. Hilgard dalam (Sumardi

Suryabrata,

1984:252) belajar merupakan proses

pebuatan yang drilakukan dengan

sengaja, yang kemudian menimbulkan perubahan, yang keadaannya berbeda dari perubahan yang ditimbulkan oleh lainnya.

Sifat perubahannya relatif permanen, tidak akan kembali kepada keadaan semula. Tidak bisa diterapkan pada perubahan akibat situasi sesaat, seperti perubahan akibat kelelahan, sakit, mabuk, dan sebagainya.

Moh. Surya (1981:32), definisi belajar adalah suatu proses usaha yang dilakukan individu untuk memperoleh suatu perubahan tingkah laku yang baru keseluruhan, sebagai hasil pengalaman individu itu sendiri dalam interaksinya dengan lingkungan.

Menurut Winkel, Belajar adalah semua aktivitas mental atau psikis yang berlangsung dalam interaksi aktif dalam lingkungan, yang menghasilkan perubahan-perubahan

dalam pengelolaan pemahaman.

Belajar menurut W. S. Wrinkel W. S. Wrinkel dalam bukunya Psikologi Pengajaran merumuskan bahwa belajar adalah suatu aktivitas mental atau psikis yang berlangsung dalam interaksi aktif dengan pengetahuan, pemahaman, ketrampilan dan nilai-nilai sikap.(W. S. Wrinkle, Psikologi Pengajaran, (Jakarta : Grasindo, 1996), hlm. 53)

Belajar adalah mencari informasi atau pengetahuan baru dari sesuatu yang sudah ada di alam. Belajar akan membawa suatu perubahan pada individu-individu yang belajar. Perubahan ini bukan hanya berkaitan dengan penambahan ilmu pengetahuan, tetapi juga bentuk kecakapan, ketrampilan, sikap, pengertian, harga diri, minat, watak dan penyesuaian diri.(Arif S. Sadiman, dkk, Media Pendidikan, (Jakarta : Raja Grafindo Persada, 2007), Cet10, hlm. 21.)

Sedangkan Pengertian Belajar menurut Gagne dalam bukunya The Conditions of Learning1977, belajar merupakan sejenis perubahan yang diperlihatkan dalam perubahan tingkah laku, yang 
Helper, Vol 35 No 1 (2018) - 33

keadaaannya berbeda dari sebelum individu berada dalam situasi belajar dan sesudah melakukan tindakan yang serupa itu. Perubahan terjadi akibat adanya suatu pengalaman atau latihan. Berbeda dengan perubahan serta-merta akibat refleks atau perilaku yang bersifat naluriah.

Dari beberapa pengertian belajar di atas maka dapat disimpulkan bahwa belajar itu bukan hanya sebatas kegiatan membaca, mendengarkan, menulis, mengerjakan tugas dan ulangan saja tapi adanya perubahan tingkah laku dari hasil kegiatan proses belajar,dimana didalam proses belajar itu ada interaksi aktif dengan lingkungan dan perubahan tersebut bersifat permanen.

Misalnya dalam pelajaran fikih diajarkan tentang macam-macam najis, setelah tahu apa itu najis dan macamnya najis maka siswa akan lebih hati-hati tentang masalah najis itu. Contoh perilakunya yaitu sebelum belajar siswa tersebut jika mau ke masjid tidak menggunakan alas kaki tetapi setelah belajar siswa tersebut jika mau ke masjid akan selalu memakai alas kaki karena takut kakinya najis jika ke masjid tanpa menggunakan alas kaki.

\section{Ciri-Ciri Belajar}

Ciri-ciri belajar adalah sebagai berikut :

1. Adanya kemampuan baru atau perubahan. Perubahan tingkah laku bersifat pengetahuan (kognitif), keterampilan (psikomotorik), maupun nilai dan sikap (afektif).

2. Perubahan itu tidak berlangsung sesaat saja melainkan menetap atau dapat disimpan.

3. Perubahan itu tidak terjadi begitu saja melainkan harus dengan usaha. Perubahan terjadi akibat interaksi dengan lingkungan.

4. Perubahan tidak sematamata disebabkan oleh pertumbuhan fisik/ kedewasaan, tidak karena kelelahan, penyakit atau pengaruh obat-obatan. 
Berikut beberapa faktor pendorong mengapa manusia memiliki keinginan untuk belajar:

1. Adanya dorongan rasa ingin tahu

2. Adanya keinginan untuk menguasai Ilmu Pengetahuan dan Teknologi sebagai tuntutan zaman dan lingkungan sekitarnya.

3. Mengutip dari istilah Abraham Maslow bahwa segala aktivitas manusia didasari atas kebutuhan yang harus dipenuhi dari kebutuhan biologis sampai aktualisasi diri.

4. Untuk melakukan penyempurnaan dari apa yang telah diketahuinya.

5. Agar mampu bersosialisasi dan beradaptasi dengan lingkungannya.

6. Untuk meningkatkan intelektualitas dan mengembangkan potensi diri.

7. Untuk mencapai cita-cita yang diinginkan.
8. Untuk mengisi waktu luang. (Belajar dan Mengajar yang Epektif Oleh Kelompok XIII, Pend. Teknik Mesin UNIMED 2011)

\section{CIRI UTAMA BELAJAR}

Menurut Gagne (Whandi: 2009) terdapat tiga atribut pokok atau ciri utama belajar, yaitu: proses, perilaku, dan pengalaman, dengan pengertian sebagai berikut :

1) Proses Belajar adalah proses mental dan emosional atau proses berpikir dan merasakan. Seseorang dikatakan belajar apabila pikiran dan perasaannya aktif. Aktifitas pikiran dan perasaan itu sendiri tidak dapat diamati orang lain, akan tetapi terasa oleh yang bersangkutan yang dapat diamati guru adalah manifestasinya, yaitu kegiatan siswa sebagai akibat dari adanya aktifitas pikiran dan perasaan pada diri siswa tersebut.

2) Perubahan Perilaku Hasil belajar berupa perubahan perilaku atau tingkah laku seseorang yang belajar akan berubah atau bertambah perilakunya, baik yang berupa 
pengetahuan, ketrampilan, atau penguasaan nilai-nilai sikap.

3) Pengalaman Belajar adalah mengalami, dalam arti belajar terjadi di dalam interaksi antara individu dengan lingkungannya, baik lingkungan fisik maupun sosial.

Lingkungan fisik, misalnya :buku, alat peraga, alam sekitar.

Lingkungan sosial, misalnya: guru, siswa pustakawan, dan Kepala Sekolah. Belajar bisa melalui pengalaman langsung maupun melalui pengalaman tidak langsung. Belajar melalui pengalaman langsung, misalnya siswa belajar dengan melakukan sendiri dan pengalaman sendiri.

Belajar melalui pengalaman tidak langsung, misalnya mengatahui dari membaca buku, mendengarkan penjelasan guru. Belajar dengan melalui pengalaman langsung hasilnya akan lebih baik karena siswa lebih memahami, lebih menguasai pelajaran tersebut, bahkan pelajaran terasa oleh siswa lebih bermakna.

Belajar sebagai perubahan tingkah laku berkat pengalaman dan latihan. Belajar membawa suatu perubahan pada individu yang belajar. Perubahan itu tidak hanya mengenai jumlah pengetahuan melainkan juga dalam bentuk kecakapan, kebiasaan, sikap, pengertian, penghargaan, minat, penyesuaian diri. Karena itu seseorang yang belajar tidak sama lagi jika dibandingkan saat sebelumnya, karena ia lebih sanggup menghadapi kesulitan memecahkan masalah atau menyesuaikan diri dengan keadaan.(Nasution, Didaktik: Asas-Asas Mengajar, Jakarta : Bumi Aksara, 2000, Cet. 2, Hlm. 35)

\section{ASPEK HASIL BELAJAR}

Benyamin S. Bloom dkk, membagi kawasan belajar yang disebut juga tujuan belajar menjadi tiga bagian atau domain, yaitu :

a. Domain kognitif terkait dengan perilaku yang berhubumgan dengan berfikir, mengetahui dan memecahkan masalah.

Domain ini memiliki enam tingkatan yaitu : pengetahuan, pemahaman, penerapan, analisis, sintesis, dan evaluasi. 
b. Domain afektif terkait dengan sikap, nilai-nilai, ketertarikan, apresiasi dan penyesuaian perasaan sosial..

Domain ini memiliki lima tingkatan yaitu : kemauan menerima, menanggapi,berkeyakinan, penerapan karya, ketekunan dan ketelitian.

c. Domain psikomotor terkait dengan keterampilan (skill) yang bersifat manual dan motorik. Domain ini memiliki tujuh tingkatan yaitu : persepsi, kesiapan melakukan suatu kegiatan, mekanisme, respon terbimbing, kemahiran, adaptasi, dan organisasi

(H. Muhammad Ali, Guru Dalam Proses Belajar Mengajar, (Bandung : Sinar Baru Algensindo, 2004), Hlm. 42-45)

\section{CIRI-CIRI}

PERUBAHAN

\section{PERILAKU DALAM BELAJAR}

1).Perubahan terjadi secara sadar

Ini berarti bahwa seseorang yang belajar akan menyadari terjadinya perubahan itu atau sekurangkurangnya ia merasakan telah terjadi adanya suatu perubahan dalam dirinya. Misalnya ia menyadari bahwa pengetahuannya bertambah, kecakapanya bertambah, kebiasaanya bertambah. Jadi perubahan tingkah laku yang terjadi karena mabuk atau dalam keadaan tidak sadar, tidak termasuk perubahan dalam pengertian belajar, karena orang yang bersangkutan tidak menyadari akan perubahan itu.

2). Perubahan dalam belajar bersifat kontinu dan fungsional

Sebagai hasil belajar, perubahan yang terjadi dalam diri seseorang berlangsung secara berkesinambungan, tidak statis. Suatu perubahan yang terjadi akan menyebabkan perubahan berikutnya dan akan berguna bagi kehidupan ataupun proses belajar berikutnya. Misalnya jika seorang anak belajar menulis maka ia akan mengalami perubahan dari tidak dapat menulis menjadi dapat menulis. Perubahan ini berlangsung terus hingga kecakapan menulisnya menjadi lebih baik dan sempurna.

3). Perubahan dalam belajar bersifat Positif dan aktif 
Dalam perbuatan belajar, perubahan-perubahan itu senantiasa bertambah dan tertuju untuk memperoleh Sesutu yang lebih baik dari sebelumnya. Dengan demikian makin banyak usaha belajar itu dilakukan, makin banyak dan makin baik perubahan yang diperoleh. Perubahan yang bersifat aktif artinya bahwa perubahan itu tidak terjadi dengan sendirinya melainkan karena usaha individu sendiri. Misalnya perubahan tingkah laku karena proses kematangan yang terjadi dengan sendirinya karena dorongan dari dalam , tidak termasuk perubahan dalam pengertian belajar.

4). Perubahan dalam belajar bukan bersifat sementara

Perubahan yang terjadi karena proses belajar bersifat menetap atau permanen. Ini berarti bahwa tingkah laku yang terjadi setelah belajar akan bersifat menetap. Misalnya kecakapan seorang anak dalam memainkan piano setelah belajar, tidak akan hilang begitu saja melainkan akan terus dimiliki bahkan akan semakin berkembang kalau terus dipergunakan atau dilatih.

5). Perubahan dalam belajar bertujuan atau terarah

Ini berarti bahwa perubahan tingkah laku itu terjadi karena ada tujuan yang akan dicapai. Perbuatan belajar terarah kepada perubahan tingkah laku yang benar-benar disadari. Misalnya seseorang yang belajar mengetik sebelumnya sudah menetapkan apa yang mungkin dapat dicapai dengan belajar mengetik, atau tingkat kecakapan mana yang akan dicapainya.

6). Perubahan mencakup seluruh aspek tingkah laku

Perubahan yang diperoleh seseorang setelah melalui suatu proses belajar meliputi perubahan keseluruhan tingkah laku. Jika seorang belajar Sesuatu, sebagai hasilnya ia akan mengalami perubahan tingkah laku secara menyeluruh dalam sikap, keterampilan, pengetahuan, dan sebagainya. 
FAKTOR-FAKTOR

\section{MEMPENGARUHI}

BELAJAR

Ada berbagai faktor yang dapat mempengaruhi proses dan hasil belajar siswa di sekolah. Secara umum, faktorfaktor tersebut terbagi menjadi tiga bagian, yaitu :

a. Faktor internal

b. Faktor ini berasal dari dalam diri siswa yakni kondisi psikologis yang berhubungan dengan jiwa siswa dan keinginan yang meliputi intelegensi, minat dan perhatian, bakat, motif serta kematangan.

1) Intelegensi

Intelegensi merupakan salah satu faktor yang berpengaruh terhadap tinggi rendahnya prestasi belajar siswa. Intelegensi merupakan dasar yang potensial bagi pencapaian hasil belajar, artinya hasil belajar yang dicapai akan sangat bergantung pada tingkat intelegensi dan hasil belajar yang dicapai tidak akan melebihi tingkat intelegensinya.(Mulyasa,
Implementasi Kurikulum 2004, Panduan Pembelajaran KBK, (Bandung : PT. Remaja Rosdakarya, 2005), Cet. V, Hlm. 193-194)

2) Minat dan perhatian

Hillgard memberikan rumusan terkait minat sebagai berikut: "interest is persisting tendency to pay attention to and enjoy some activity or content".(Slameto, Belajar Dan Faktor-Faktor Yang Mempengaruhinya, (Jakarta : Rineka Cipta, 2010), Cet. V, Hlm. 57)

Minat dapat diartikan sebagai kecenderungan seseorang terhadap sesuatu, sedangkan perhatian adalah melihat dan mendengarkan dengan baik dan teliti terhadap sesuatu.(Abdul Wahib, Menumbuhkan Bakat Dan Minat Anak, dalam Chabib Thoha dan Abdul Mu'thi, PBMPAI di Sekolah, Eksistensi dan Proses Belajar Mengajar Pendidikan Agama Islam, (Yogyakarta : Pustaka Pelajar, 1998), Hlm. 79) 
Perhatian dapat dipupuk dengan

memberikan stimulus yang baru, beraneka ragam atau berorientasi tinggi.(S. Nasution, Berbagai Pendekatan Dalam Proses Belajar Mengajar, (Jakarta : Bumi Aksara, 2000), Hlm. 180)

Minat mempunyai pengaruh besar terhadap belajar, karena bila bahan ajar yang dipelajari tidak sesuai dengan minat siswa, maka siswa tidak akan belajar dengan sebaik-baiknya, karena tidak adanya daya tarik. Dengan adanya minat siswa terhadap materi pelajaran akan memberikan hasil positif terhadap hasil atau prestasi belajarnya.

\section{3) Bakat}

Bakat atau aptitude menurut Hillgard adalah "the capacity to learn”. Dengan kata lain bakat adalah kemampuan untuk belajar.(5 Slameto, Op. Cit., Hlm. 57)

Kemampuan ini akan terwujud menjadi kecakapan yang nyata setelah belajar atau berlatih.
Secara umum bakat mirip dengan intelegensi. Melihat hubungan yang erat antara bakat dengan hasil belajar maka terdapat dua alasanmengapa bakat harus diketahui oleh guru sebagai pendidik dan orang tua sebagai penaggung jawab masa depannya.

Pertama, orang tua dan guru dapat memenuhi segala kebutuhan anak berbakat tersebut sehingga bakat yang dimiliki anak dapat berkembang dengan baik. Kebutuhan tersebut meliputi kebutuhan kognitif maupun kebutuhan afektif. Orang tua dapat menyediakan lingkungan pendidikan yang tepat bagi perkembangan bakat anak. Tujuan pemilihan lingkungan pendidikan tersebut tidak lain adalah membantu anak untuk memahami diri sendiri agar menerima bakat yang dimiliki sebagai suatu anugrah yang harus disyukuri dan dikembangkan, bukan sebagai 
suatu beban.( Abdul Wahib., Hlm. 108)

Kedua, orang tua dan guru dapat membantu memberikan informasi yang diperlukan untuk mengembangkan bakat anak tersebut. Transfer informasi yang terjadi diantara orang tua dan guru kepada siswa akan menjadi sebuah dukungan yang dibutuhkan siswa dalam menjalani proses belajarnya.

4) Motif

James Drever memberikan definisi terkait motif yaitu : Motive is an effective-conative factor which operates in determining the direction of an individual's behavior to wards an end or goal, consioustly apprehended or unconsioustly.(Slameto, Hlm. 58)

Motif dapat diartikan sebagai dorongan yang membuat seseorang berbuat sesuatu. Motif selalu mendasari dan mempengaruhi setiap usaha serta kegiatan seseorang untuk mencapai tujuan tertentu. Motif yang kuat akan berpengaruh terhadap seberapa besar usaha dan kegiatan untuk mencapai tujuan belajar.

5) Kematangan

Kematangan adalah tingkat atau fase dalam pertumbuhan seseorang, dimana alat-alat tubuhnya sudah siap untuk melaksanakan kecakapan baru.

b. Faktor eksternal yang berasal dari lingkungan sekitar siswa.

1) Cara orang tua mendidik Cara orang tua mendidik sangat berpengaruh terhadap hasil belajar anak. Hal ini dipertegas oleh Sutjipto Wirowidjojo yang menyatakan bahwa :

Keluarga merupakan lembaga pendidikan yang pertama dan utama. Keluarga yang sehat besar, artinya untuk pendidikan dalam ukuran kecil, tetapi bersifat menentukan untuk pendidikan dalam ukuran besar. Orang tua yang tidak atau kurang memperhatikan pendidikan anak, misalnya acuh terhadap 
belajar anak dan sebagainya dapat menyebabkan anak tidak atau kurang berhasil dalam belajarnya. Mendidik anak dengan memanjakannya adalah cara mendidik yang tidak baik.

Orang tua yang terlalu kasihan terhadap anak bahkan tidak sampai hati untuk memaksa anak untuk belajar, bahkan membiarkan saja jika anaknya tidak belajar dengan alasan apapun adalah tidak benar, sebab jika hal ini dibiarkan berlarutlarut akan menjadikan anak nakal, berbuat seenaknya dan akan menimbulkan kekacauan dalam belajar anak. Mendidik anak dengan cara terlalu keras juga salah, sebab dengan cara demikian anak akan diliputi ketakutan dan akhirnya benci terhadap belajar. Bahkan dengan ketakutan tersebut dapat menyebabkan gangguan jiwa akibat tekanan-tekanan yang dilakukan orang tua.

Disini bimbingan dan penyuluhan memegang peranan penting. Anak atau siswa yang mengalami kesulitan-kesulitan belajar dapat ditolong dengan memberikan bimbingan belajar dengan sebaik-baiknya dan peran orang tua akan mempengaruhi keberhasilan bimbingan tersebut.

2) Pengertian orang tua

Anak yang belajar memerlukan dorongan dan pengertian dari orang tua. Bila anak sedang belajar tidak boleh ada gangguan dalam bentuk apapun. Terkadang anak mangalami lemah semangat, kewajiban orang tua adalah memberi pengertian dan dorongan semangat, membantu sedapatnya terkait kesulitankesulitan yang dialami anak.

3) Relasi antaranggota keluarga Relasi antaranggota keluarga yang terpenting adalah relasi antara orang tua dengan anak. Selain itu relasi anak dengan saudaranya atau dengan anggota keluarga yang lainpun ikut mempengaruhi belajar anak. Sebetulnya relasi antaranggota 
keluarga erat hubungannya dengan cara orang tua mendidik anak. Demi kelancaran belajar serta keberhasilan anak, perlu diusahakan relasi yang baik di dalam keluarga anak tersebut.

c. Faktor pendekatan belajar (approach to learning), jenis upaya belajar siswa yang meliputi strategi dan metode yang digunakan siswa untuk melakukan kegiatan pembelajaran materi-materi pelajaran.(Muhibbin Syah, Psikologi Pendidikan Dengan Pendekatan Baru, (Bandung : Remaja Rosdakarya, 2005), Hlm. 132)

\section{d. Faktor sekolah}

1) Kurikulum

Kurikulum adalah a plan for learning yang merupakan unsur substansial dalam pendidikan.(Syaiful Bahri Djamarah, Psikologi Belajar, (Jakarta : Rineka Cipta, 2002), Cet I, Hlm. 146)

Tanpa kurikulum, kegiatan belajar mengajar tidak dapat berlangsung, sebab materi yang harus disampaikan oleh guru harus sesuai dengan kurikulum yang ada. Muatan kurikulum akan mempengaruhi intensitas dan frekuensi belajar anak.

2) Metode mengajar Metode mengajar adalah suatu cara atau jalan yang harus dilalui dalam mengajar. Definisi mengajar sendiri menurut Ign. S. Ulih Bukit Karo Karo adalah menyajikan bahan pelajaran oleh seseorang kepada orang lain agar orang tersebut menerima, menguasai dan mengembangkannya. Metode mengajar sangat mempengaruhi belajar. Metode mengajar guru yang kurang baik akan mempengaruhi belajar siswa yang tidak baik pula

\section{3) Guru}

Guru mempunyai peran penting dalam menentukan hasil belajar dan prestasi siswa, karena hampir seluruh aktivitas siswa sangat bergantung kepada guru. Dalam hal ini efektivitas 
pengelolaan bahan ajar, lingkungan dan instrument sebagai faktor utama yang mempengaruhi proses dan prestasi belajar.

e. Faktor lingkungan masyarakat

1) Kegiatan siswa dalam masyarakat

Kegiatan siswa dalam masyarakat dapat memiliki dampak menguntungkan tetapi juga dapat merugikan. Menguntungkan bagi perkembangan pribadinya. Merugikan bila siswa terlalu banyak mengikuti kegiatan dalam masyarakat. Hal ini dapat mengganggu belajarnya, bila siswa tidak bijak dalam mengatur waktu.

2) Media massa

Media massa memiliki dampak positif dan juga negatif bagi perkembangan belajar siswa. Diharapkan bimbingan dari orang tua maupun pendidik dalam penggunaan media massa.

3) Teman bergaul
Pengaruh dari teman akan lebih cepat masuk ke dalam jiwa siswa. Agar siswa dapat belajar dengan baik, maka perlu diusahakan agar siswa dapat memiliki teman bergaul yang baik dan pembinaan pergaulan yang baik serta pengawasan dari orang tua dan pendidik.

4) Bentuk kehidupan masyarakat Kehidupan masyarakat di sekitar siswa juga mempengaruhi belajar siswa. Kehidupan masyarakat yang bermacammacam akan berpengaruh kuat terhadap belajar siswa. Orang tua perlu mengusahakan lingkungan yang baik agar dapat memberi pengaruh yang positif terhadap siswa, sehingga dapat belajar dengan sebaik-baiknya.

\section{PENILAIAN TERHADAP HASIL BELAJAR}

Belajar mengajar sebagai suatu proses mengandung tiga unsur yang dapat dibedakan yaitu : tujuan pembelajaran (instruksional), pengalaman (proses) belajar mengajar, dan hasil belajar. Salah 
Helper, Vol 35 No 1 (2018) - 44

satu upaya untuk mengetahui hasil belajar yaitu melalui sistem penilaian. Penilaian adalah upaya untuk mengetahui sejauh mana ketercapaian tujuan pembelajaran. Dengan kata lain, penilaian berfungsi sebagai alat untuk mengetahui keberhasilan proses atau hasil belajar siswa. Penilaian hasil belajar mengajar adalah proses pemberian nilai terhadap hasil-hasil belajar yang telah dicapai siswa dengan kriteria tertentu. Hasil belajar siswa pada hakikatnya adalah perubahan tingkah laku sebagai hasil belajar, dalam arti luas mencakup bidang kognitif, afektif dan psikomotorik.

Adapun fungsi dari penilaian adalah :

a. Untuk melihat sejauh mana kemajuan, kegagalan dan kesulitan belajar yang telah dialami oleh siswa dalam suatu program pembelajaran.

b. Untuk penyeleksian dalam rangka penerimaan siswa baru dan atau melanjutkan ke jenjang berikutnya.

c. Untuk menetapkan siswa mana yang memenuhi ranking atau kurang, yang telah ditetapkan dalam rangka kenaikan kelas. d. Penyedia data tentang lulusan agar dapat ditempatkan sesuai dengan kemampuannya.(Nana Sudjana, Penilaian Hasil Proses Belajar Mengajar

(Bandung : Remaja Rosdakarya, 1999), Cet. IV, Hlm. 160 )

\section{DAFTAR PUSTAKA}

Abdul Wahib, Menumbuhkan Bakat Dan Minat Anak, dalam Chabib Thoha dan Abdul Mu'thi, PBMPAI di Sekolah, Eksistensi dan Proses Belajar Mengajar Pendidikan Agama Islam, (Yogyakarta : Pustaka Pelajar, 1998), Hlm. 79

Ali H. Muhammad, Guru Dalam Proses Belajar Mengajar, (Bandung : Sinar Baru Algensindo, 2004), Hlm. 42-45

Arif S. Sadiman, dkk, Media Pendidikan, (Jakarta : Raja Grafindo Persada, 2007), Cet10, hlm. 21 .

Mulyasa, Implementasi Kurikulum 2004, Panduan Pembelajaran KBK, (Bandung : PT. Remaja Rosdakarya, 2005), Cet. V, Hlm. 193-194)

Nasution, Berbagai Pendekatan Dalam Proses Belajar Mengajar, (Jakarta : Bumi Aksara, 2000), Hlm. 180 
S. Nasution, Didaktik: Asas-Asas Mengajar, Jakarta : Bumi Aksara, 2000, Cet. 2

Slameto, Belajar Dan Faktor-Faktor Yang Mempengaruhinya, (Jakarta : Rineka Cipta, 2010), Cet. V, Hlm. 57

Belajar dan Mengajar yang Epektif Oleh Kelompok XIII, Pend. Teknik Mesin UNIMED 2011

Suryabrata Sumadi, Psikologi Pendidikan, (Jakarta : Rajawali, 1984)
W. S. Wrinkle, Psikologi Pengajaran, (Jakarta : Grasindo, 1996), hlm. 53

http://belajarpsikologi.com/pengertianbelajar-menurut-ahli/ (diakses 16 Nop 2017)

https://www.kompasiana.com/pughiyman/a pa-itu-

belajar_55004441a333115b745101ea (diakses 17 Nop 2017)

http://eprints.walisongo.ac.id/544/3/073

811027_Bab2.pdf 
Helper, Vol 35 No 1 (2018) - 46

"HELPER" Jurnal Bimbingan dan Konseling FKIP UNIPA 